\title{
Optimization of extrusion variables for the production of snacks from by-products of rice and soybean \\ Lairy Silva COUTINHO ${ }^{1 *}$, Jaqueline Eduarda Rodrigues BATISTA ${ }^{1}$, Márcio CALIARI ${ }^{1}$, Manoel Soares SOARES JÚNIOR ${ }^{1}$
}

\begin{abstract}
This study aimed to define the process conditions to obtain snacks from the by-products of rice and soybean with physical characteristics suitable for marketing. Therefore, the effects of moisture and extrusion temperature on the expansion and color of the products obtained experimentally obtained were evaluated, and the proximate composition of the by-products and that of the snack with greater desirability were determined. Response surface methodology and rotational central composite design were used, and desirability test based on the regression models adjusted was applied. The most desirable snack, with the highest expansion index (3.39), specific volume $\left(13.5 \mathrm{~mL} \cdot \mathrm{g}^{-1}\right)$, and the chromaticity coordinate $\mathrm{a}^{*}(2.79)$, was obtained under $12 \mathrm{~g} .100 \mathrm{~g} \mathrm{~g}^{-1}$ moisture and $85^{\circ} \mathrm{C}$ of temperature in the third zone of the extruder. The snack produced under these conditions attained content of protein and lipid content 41 and $64 \%$ higher than that of the traditional corn snack. It can be concluded that producing extruded snack made form a mixture of broken grains, rice bran, and soybean okara (81:9:10) is technologically feasible, enabling the development of a new product with good nutritional value that can improve the diet of children, the main consumers of this type of food.
\end{abstract}

Keywords: Oriza sativa L.; Glycine max L.; processing; expansion; color; sustainability.

\section{Introduction}

Corn grits are the main raw material for commercial production of extruded snacks. They have high porosity, crunchy texture, and are palatable Ascheri et al. (2003). Recently, some other raw materials, mainly agribusiness by-products derived from the processing of grains, roots, and tubers have been studied in order to replace corn grits in the manufacture of snacks. Some starch-rich by-products are economically viable, and therefore are more convenient for obtaining expanded products (SOARES JUNIOR et al., 2011; CARVALHO et al., 2012). Brazil has an outstanding production of rice (Oryza sativa L.) and soybean (Glycinemax L.) generating large amounts of by-products in the processing of these commodities.

Rice is the second largest produced cereal worldwide, behind wheat only. It is estimated that in the 2012 crop, 730 million tons of paddy rice were produced. Brazil has a good share in world production of this grain and is considered the tenth global consumer (FOOD..., 2013). The estimated world production of soybean in the 2012 was 271.3 million tons, and Brazil produced 78 million tons, the second largest producer (HECK, 2012).

During rice processing, broken grains rich in carbohydrates (89.9 g.100 g ${ }^{-1}$ ), mainly starch and bran, are generated. These grains have variable amounts of starch, but they are nutritionally beneficial because they are a source of protein $\left(13.4 \mathrm{~g} .100 \mathrm{~g} \mathrm{~g}^{-1}\right)$ (PESTANA, MENDONÇA, ZAMBIAZI, 2008).

In addition to the intensive use of soybean for the production of oil and meal, there has been an increased use of water soluble soybean extract or soy milk. The soybean market has been growing markedly in recent years (93\%), especially in the beverage segment, and the ready-to-drink juice market has grown $25 \%$ in the same period due to consumer demand for healthy and practical products (JAEKEL; RODRIGUES; SILVA, 2010). Thus, there has been a large production of rice and soybean by-products derived from the manufacturing process of these grains.

Okara is the residue obtained, specifically in the filter, in the production of water soluble soybean extract (SILVA; CARRÃO-PANIZZI; PRUDÊNCIO, 2009). With regard to chemical composition, okara has high protein, averaging $42.5 \%$ on a dry basis. Approximately one third of soybean isoflavones remain in okara. Thus, this by-product, in addition to having the potential to be used as a source of nutrients, it is also a source of isoflavones (LI et al., 2012). Studies indicate that the consumption of soybean by-products and their derivatives provides health benefits, such as prevention and therapeutic treatment of cardiovascular diseases reduced risk of cancer and osteoporosis, and alleviation of menopausal symptoms (MOLINA; FEIHRMANN, 2009).

The production of extruded snacks from the by-products of rice and soybean can be a great alternative to producing processed food of commercial interest due to the expansion characteristics of the mixture (rich in starch) and the nutritional value from the higher protein content and better profile of essential amino acids of soybean and rice relative to corn 
(LI et al., 2012; LIMBERGER et al., 2009). In the present study, the best extrusion condition was determined considering the aspects of expansion and color as a function of the mixture moisture and temperature in the third zone of the extruder, in addition to the physical and chemical quality parameters of the snacks produced using the best technological condition.

\section{Materials and methods}

The broken grains and rice bran (blend of the cultivars IRGA 417 and IRGA 424-2012 harvest), were donated by the company Cristal Alimentos Ltda., located in Aparecida de Goiânia (Goiás, Brazil); black soybean was acquired in Cerealista São José, located in São Paulo (São Paulo, Brazil). The rice by-products, broken grains and rice bran, were used on the day following their production in the form they were acquired. In order to obtain the dried black soybean okara, the grains were soaked in boiling water for 5 minutes to inactivate the antinutritional factors of the legume, according to Bellaver and Snizek Junior (2009). The okara produced was dried in an air circulation oven (Technal TE-394, Piracicaba, Brazil) at $60{ }^{\circ} \mathrm{C}$ for 10 hours.

The particle size of the by-products of rice and soybean was determined using a vibrating equipment (Produtest, Mod. T, São Paulo, Brazil), according to the method described by Dias and Leonel (2006). Micrographs of the by-products were obtained using a scanning electron microscope (Sputter Coater, SCD-050, Scotia, USA), with 3000x and $6000 \mathrm{x}$ magnification, after drying the samples in an air circulation oven at $60^{\circ} \mathrm{C}$ for 24 hours; The samples remained in a desiccator until analysis. They were then mounted with double-sided tape on aluminum stubs and were coated with gold (15 $\mathrm{nm}$ thick).

After the preliminary tests, the snacks were prepared from a mixture of broken rice grains, rice bran, and dried black soybean okara (81: 9: 10), homogenized for 15 minutes using a Y-type mixer. The mixture was packed using different moisture levels according to the values set in the experimental design. The coded values of the independent variables were-1.41; $-1 ; 0 ; 1$; and 1.41, while the actual temperature values of the third zone of the extruder ranged between 60 and $110^{\circ} \mathrm{C}$ and moisture between 12 and $20 \mathrm{~g} .100 \mathrm{~g}^{-1}$. The samples with different moisture contents were kept under refrigeration for 24 hours before use. The amount of water to be added to the samples was calculated based on the amount of mixture to be extruded and on its initial moisture content (Equation 1).

$$
Q_{w}=\left\{\left[\frac{\left(M_{f}-M_{i}\right)}{\left(100-M_{f}\right)}\right] * 100\right\} * M_{s}
$$

where: $\mathrm{Q}_{\mathrm{w}}=$ quantity of water to be added into the mixture (g); $\mathrm{M}_{\mathrm{f}}=$ final moisture content $\left(\mathrm{g} .100 \mathrm{~g}^{-1}\right) ; \mathrm{M}_{\mathrm{i}}=$ initial moisture content of the sample $\left(\mathrm{g} .100 \mathrm{~g}^{-1}\right)$; and $\mathrm{M}_{\mathrm{s}}=$ mass of the sample (g).

The thermoplastic extrusion was performed using a single screw extruder machine (Inbramaq, PQ-30, Ribeirão Preto, Brazil). The processing parameters used were: screw speed of $250 \mathrm{rpm}(60 \mathrm{~Hz})$, circular die opening of $4 \mathrm{~mm}$ diameter, pre- die with 22 holes, screw with three inputs and $30 \mathrm{~cm}$ length, screw compression ratio of $3: 1$, helical barrel design, feed rate (335 g. $\mathrm{min}^{-1}$ ); and barrel temperature in the first and second heating zone of $40^{\circ} \mathrm{C}$ and $60^{\circ} \mathrm{C}$, respectively.

The volume of the snacks was determined according to the mass displacement method (millet seed) in 10 replications; the mass was measured using a semi-analytical scale. The specific volume (SV) was calculated by the ratio between the average volume and the mass of snacks, according to the method described by Leonel, Souza and Mischan (2010). The expansion index (EI) was determined by the ratio between the diameter of the extrudate and the diameter of the output hole of the extruder ( $4 \mathrm{~mm}$ ), according to the method described by Faubion and Hoseney (1982). A caliper (Digital Caliper, Messen, Danyang, China) was used to measure the diameter of the extrudate, and the arithmetic mean was calculated from 10 randomly chosen snacks per experiment. The snacks were evaluated for instrumental parameters of color, following the method proposed by Paucar-Menacho et al. (2008), according to the CIEL L* ${ }^{*}{ }^{*}$ and $\mathrm{b}^{*}$ system with a colorimeter (Color Quest, XE, Reston, EUA) using the standard illuminant D65 (corresponding to natural daylight), and an observation angle of $10^{\circ}$.

The proximate composition and energy value of the rice and soybean by-products and the selected snack were determined. Moisture was determined as the mass loss measured by drying the sample in an oven at $105^{\circ} \mathrm{C}$ until constant weight. Protein concentration was determined by the Kjeldahl method for the determining total nitrogen content, which was converted into crude protein by the conversion factor of 6.25 for soybean and 5.95 for rice by-products. Lipid content was determined by the Bligh-Dyer method for cold extraction with chloroform, methanol and water at the ratio of 1:2:0.8 (v/v); ash content was determined by carbonization, followed by complete incineration in a muffle furnace at $550^{\circ} \mathrm{C}$, and carbohydrates were calculated by difference by as $100-$ (moisture + ash + protein + fat $)$ (ASSOCIATION..., 2005). The crude fiber was determined by the Scharrer-Kürschner method, as described by Angelucci et al. (1987), using nitric acid, trichloroacetic acid, and acetic acid for hydrolysis. The total energy was estimated using the Atwater conversion factors; the content of carbohydrate (minus the crude fiber content) and protein were multiplied by four; lipid content was multiplied by nine, and the sum of the products' content resulted in the value of total energy (BRASIL, 2003). The chemical composition data of the snacks evaluated were compared with those of the corn snacks reported by Bombo (2006).

The Central Composite Rotational design was used with 11 experiments and three replicates at the central point (RODRIGUES; IEMMA, 2005). Data from EI, SV, L* and chrome $\mathrm{a}^{\star}$ and $\mathrm{b}^{*}$ of the snacks were evaluated by analysis of variance with the construction of multiple regression models and level curves to identify the effect of the independent variables on the responses using the Statistica software (Statsoft, Statistica 7.0, Tulsa, USA). Based on the significant mathematical models $(\mathrm{P}<0.10)$ and using the function Response Desirability Profiling of the software Statistica, the most desirable snack depending on the moisture and extrusion temperature used 
was determined. The most desirable snack was considered the one with higher values of EI, SV, and chromaticity $\mathrm{a}^{*}$. The optimization technique was based on the definition of a function of restricted desirability in the range $0-1$, for which the lower, middle, and upper limit values were defined as $0,0.5$, and 1.0, respectively, for the dependent variables studied (STASOFT, 2007). After determining the best process conditions to obtain the most desirable snack, a new extrusion was carried out under these conditions to validate the mathematical models.

\section{Results and discussion}

The low levels of moisture found in the by-products are desirable (Table 1) since moisture values below 14 g. $100 \mathrm{~g}^{-1} \mathrm{can}$ prevent microbial growth, improve chemical and enzymatic stability, and increase the shelf life of products (BARBOSACÁNOVAS et al., 2007). The ash content of rice bran was 45 times higher than that of the broken grains and 9 times higher than that of the okara soybean, which may be an advantage in terms of mineral contents, while the mean value of lipids in the broken rice grains was low, $4 \%$ less than that found in okara and $5 \%$ less than that of rice bran.

The soybean okara showed values 7.2 and 41.2 times higher in protein and crude fiber, respectively, than those of the broken rice grains, which had 43 and $172 \%$ more total carbohydrates than rice bran and soybean okara, respectively. Soybean okara showed the highest total energy, 14\% higher than that of the rice bran and 32\% higher than that of the broken rice grains. Based on the determination of crude fiber rather than the determination of dietary fiber, the fiber content was underestimated. On the other hand, the energy value was overestimated. The results obtained indicate that the rice bran and soybean okara were rich in lipid, protein, and fiber, which increase the energy value.

The particle size data of rice and soybeans are shown in Table 2. The uniformity index (UI) of the broken rice grains was 6:4:0 (60\% coarse particles and 40\% medium particles); for soybean okara it was 7:3:0 and for rice bran it was 0:6:4. Therefore, soybean okara was the by-product with highest uniformity.

It can be considered that the soybean okara and broken rice grains had a coarser particle size (100\% of the particles were medium sized and coarse), similar or even larger than those of the corn grits (ASCHERIR et al., 2002). In contrast, rice bran showed finer grain size (100\% between medium and fine), which were obtained due to bran removal and grain polishing during processing. Working with large particles of broken grains and okara without prior grinding facilitated feeding the extruder avoiding the formation of air chambers within the volumetric feeder. Despite the differences in particle size of the mixture's components, there was no negative effect on the extrusion process. The homogeneity of the particles promotes the proper and uniform cooking of the raw material during the extrusion process by preventing hardness and partial cooking, which causes undesirable particles with different degrees of cooking compromising the quality of the extruded product, both in terms of appearance and palatability (BORGES et al., 2003). In the present study, the presence of unwanted particles in the snacks was observed only under milder process conditions, low temperature and low moisture.

The rice broken grains and rice bran showed large amounts of uniform microscopic appearance with rounded starch granules with an average diameter of $5.4 \mathrm{~m}$, which were either loose or clustered in a protein matrix, but intact (Figure 1A and 1C). In the rice bran it was also observed the presence of fibers derived from the pericarp of the caryopsis, while the okara had uneven elongated shape structures typical of soybean protein and fiber (Figure 1B).

The influence of moisture and temperature on the final appearance of the snacks obtained in the different treatments was evident (Figure 2). The snacks extruded at lower levels of

Table 1. Proximate composition and energy value of the rice and soybean by-products ${ }^{1}$.

\begin{tabular}{cccc}
\hline Component & Broken rice grains & Rice bran & Black soybean okara \\
\hline Moisture $^{2}$ & $10.45 \pm 0.19(1.86)$ & $3.54 \pm 0.17(4.99)$ & $2.26 \pm 0.04(1.61)$ \\
Ashes $^{2}$ & $0.22 \pm 0.02(11.7)$ & $10.20 \pm 0.19(1.83)$ & $2.27 \pm 0.14(6.18)$ \\
Lipids $^{2}$ & $0.96 \pm 0.06(5.94)$ & $18.32 \pm 0.07(0.36)$ & $24.73 \pm 0.11(0.43)$ \\
Protein $^{2}$ & $6.52 \pm 0.16(2.41)$ & $10.89 \pm 0.14(1.25)$ & $40.66 \pm 0.07(0.16)$ \\
Crude fiber $^{2}$ & $0.17 \pm 0.02(11.76)$ & $5.61 \pm 0.13(2.31)$ & $7.07 \pm 0.20(2.83)$ \\
Total carbohydrates $^{2}$ & 81.85 & 57.05 & 30.08 \\
Energy value $^{3}$ & 361.39 & 418.90 & 477.17 \\
\hline
\end{tabular}

${ }^{1}$ Mean value \pm standard deviation (coefficient of variation); ${ }^{2} \mathrm{~g} .100 \mathrm{~g}^{-1} ;{ }^{3} \mathrm{kcal} .100 \mathrm{~g}^{-1}$.

Table 2. Percentage of samples retained on the sieves during the analysis of the particle size of the by-products of rice and black soybean used in the formulation of snacks.

\begin{tabular}{ccccc}
\hline Tyler & Hole $(\mathrm{mm})$ & Rice bran $(\%)$ & Broken rice grains $(\%)$ & Soybean okara $(\%)$ \\
\hline 32 & 2.00 & 3.31 & 62.76 & 36.92 \\
68.74 \\
60 & 0.25 & 63.07 & 0.32 & 31.02 \\
100 & 0.15 & 32.06 & 0 & 0.24 \\
150 & 0.106 & 1.28 & 0 & 0 \\
270 & 0.053 & 0.28 & 0 & 0 \\
Sieve bottom & 0 & 0 & 0 \\
\hline
\end{tabular}


moisture and temperature in the third zone of the extruder were grayish, lighter than those in the treatments with higher moisture and lower temperatures, which were expanded and darker snacks.

The experimental design and the results are shown in Table 3. The significance levels of the effect of temperature and moisture (linear, quadratic, and interaction), the model adjusted, and coefficient of determination $\left(\mathrm{R}^{2}\right)$ of the properties expansion and color are shown in Table 4.

The models for brightness $\left(\mathrm{L}^{*}\right)$ and chromaticity coordinate $\mathrm{b}^{*}$ were not significant $(\mathrm{P}>0.10)$. The other models were significant $(\mathrm{P} \leq 0.10)$, with coefficients of determination explaining between 67 and $80 \%$ of the responses. The EI of the snacks ranged from 2.33 to 3.61 , with a difference of $55 \%$ between the treatments. The quadratic effects of temperature and moisture and the linear effect of moisture were significant in the model $(\mathrm{P}<0.10)$ (Table 4$)$. The graph area with higher EI values (above 3.0 ) has a semi-elliptical shape and is situated between moisture values of 13.2 to $16.2 \mathrm{~g} \cdot 100 \mathrm{~g}^{-1}$ and temperatures above $83^{\circ} \mathrm{C}$ (Figure $3 \mathrm{~A}$ ).

Silva and Ascheri (2009) extruding broken rice found values of EI between 3.5 and 11.2. The highest values were observed with humidity between $15-16 \%$ and temperatures between 140 $160{ }^{\circ} \mathrm{C}$. In the present study, the maximum temperature used was $110^{\circ} \mathrm{C}$ and the use of rice bran and soybean okara (rich in fiber and lipids) (Table 1) may explain the lower IS values obtained. Aschieri and Carvalho (2006) studied extrusion of rice flour with 10,15 , and $20 \%$ of soybean peels (crude fiber ranging from 14.54 to 20.1) and obtained EI values between 4.37 and 4.90. The presence of fiber can break the walls of the bubbles in the product preventing its maximum expansion (LUE; HSIEH; HUFF, 1991). According to Soares Junior et al. (2011), snacks with different proportions of rice flour and bean flour (3.2-5.3\% lipids) resulted in EI values between 2.0 and 3.9. The treatment with less bean flour showed the highest EI. Kumagai, Lee and Yano (1987) observed that the volume of extruded made with defatted rice flour was $50 \%$ larger than that of the extruded
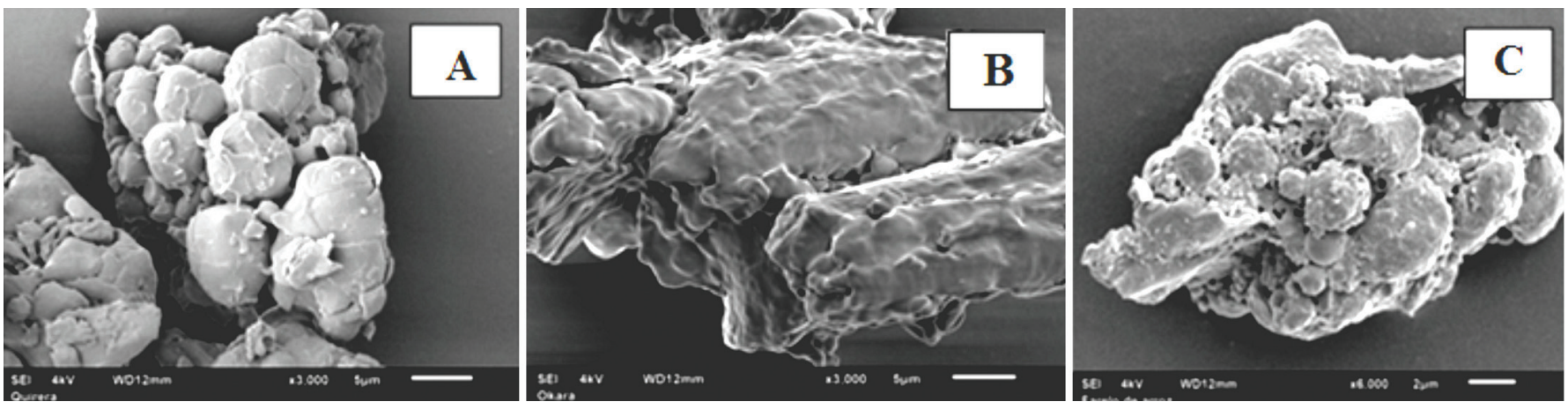

Figure 1. Scanning electron microscopy: (A) broken rice grains at 3000x magnification, (B) dried black soybean okara at 3000x; (C) rice bran at $6000 x$.
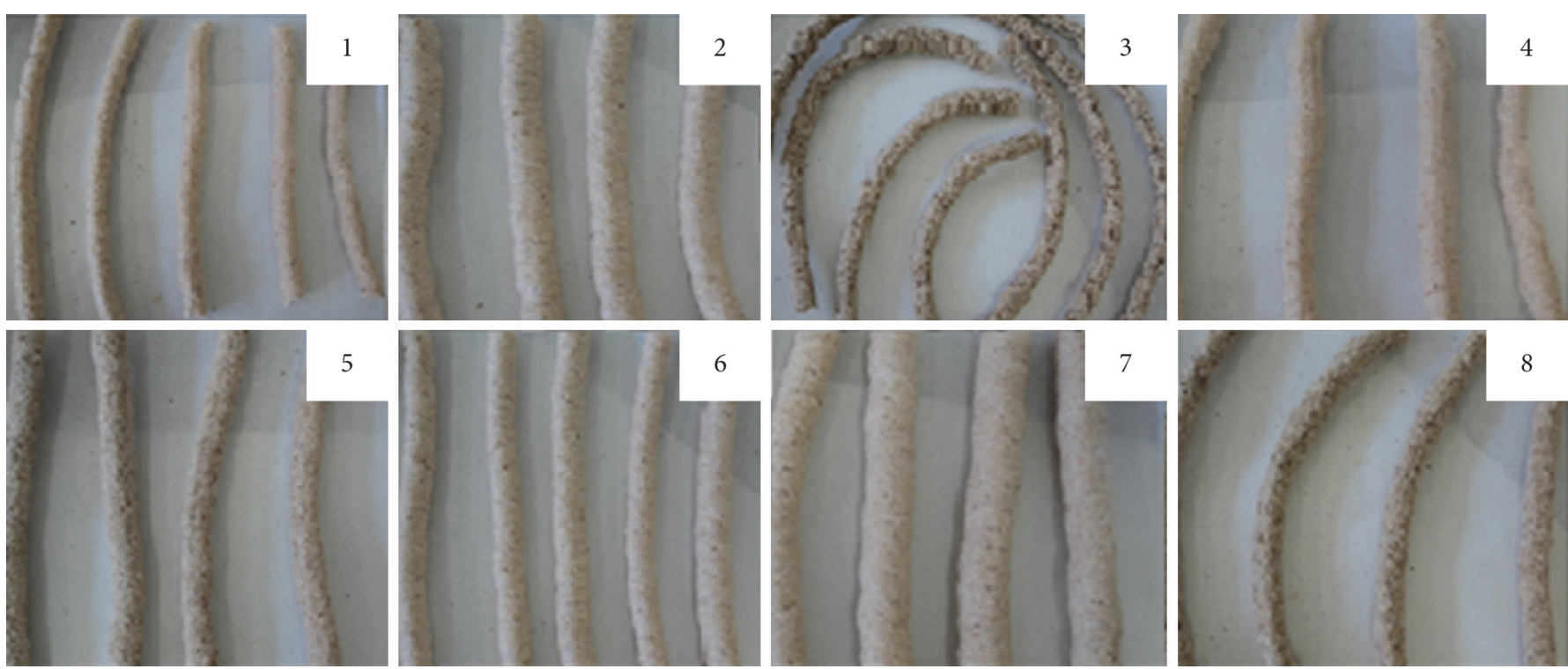

Figure 2. General appearance of experimental snacks produced from by-products of rice and soybean (experiment 1-8). Experiment 1 (moisture 13.16 g. $100^{-1}$; temperature $67.3^{\circ} \mathrm{C}$ ); experiment 2 (moisture 13.16 g. $100^{-1}$; temperature $102.7^{\circ} \mathrm{C}$ ); experiment 3 (moisture 18.84 g. $100^{-1}$; temperature $67.3^{\circ} \mathrm{C}$ ); experiment 4 (moisture 18.84 g. $100^{-1}$; temperature $102.7^{\circ} \mathrm{C}$ ); experiment 5 (moisture 16 g. $100^{-1}$; temperature $60^{\circ} \mathrm{C}$ ); experiment $6($ moisture 16 g. $100^{-1}$; temperature $110^{\circ} \mathrm{C}$ ); experiment 7 (moisture 12 g. $100^{-1}$; temperature $85^{\circ} \mathrm{C}$ ); experiment 8 (moisture 20 g. $100^{-1}$; temperature $85^{\circ} \mathrm{C}$ ). 
rice flour. In the present study, the radial expansion was less pronounced, probably due to the lipid content of the rice bran and soybean okara.

As for the SV, there was a variation of $133 \%$, from 5.9 to $13.8 \mathrm{~mL} \cdot \mathrm{g}^{-1}$. The linear trend of moisture was negative and significant, while that of interaction was positive and significant $(\mathrm{P}<0.10)$. (Table 4). The highest values of SV (above $12.0 \mathrm{~mL} \cdot \mathrm{g}^{-1}$ ) were found in the area comprising temperatures below $92^{\circ} \mathrm{C}$ and moisture below $13.6 \mathrm{~g} .100 \mathrm{~g}^{-1}$, and the lowest SV values (below 7,5 mL.g ${ }^{-1}$ ) were found at temperatures above $102^{\circ} \mathrm{C}$ and moisture above $16.6 \mathrm{~g} .100 \mathrm{~g}^{-1}$ (Figure 3B). According to Ding et al. (2005), water has the opposite effect on expansion, acting as a plasticizer for starch materials, reducing its viscosity and dissipating the mechanical energy in the extruder, and thus the product becomes denser and the bubble growth is compressed, as observed in the present study. Camargo, Leonel and Mischan (2008) studied the effect of moisture and extrusion temperature on the specific volume of snacks of cassava starch and soy flour, and reported values between 1.5 to $5.6 \mathrm{~mL} . \mathrm{g}^{-1}$, which are lower than those found in the present study.

Corn snacks usually have specific volume with values similar to those found in the present study. Alves and Grosmann (2002) reported that the SV of commercial corn snacks can reach up to $8.4 \mathrm{~mL} . \mathrm{g}^{-1}$, value within the range of SV observed for the snack produced from rice and soybean by-products.

The color of the snacks is a very important feature for the marketing, and it is influenced by the raw materials that make up

Table 3. Experimental design and results of expansion index (EI), specific volume (SV), brightness $\left(\mathrm{L}^{\star}\right)$, chromes $\mathrm{a}^{\star}$ and $\mathrm{b}^{\star}$, and color difference (DE) compared to the color of raw mixture $(\mathrm{A})$ of the extruded snacks according to temperature $\left(\mathrm{x}_{1}\right)$ and moisture $\left(\mathrm{x}_{2}\right)$.

\begin{tabular}{|c|c|c|c|c|c|c|c|}
\hline \multirow{2}{*}{ Exp. } & \multicolumn{2}{|c|}{ Encoded value } & \multicolumn{2}{|c|}{ Real value } & \multicolumn{3}{|c|}{ Physical property } \\
\hline & Temp. $\left(\mathrm{x}_{1}\right)$ & Moisture $\left(\mathrm{x}_{2}\right)$ & Temp. $\left({ }^{\circ} \mathrm{C}\right)$ & Moisture (g.100g-1) & SV & EI & $\mathrm{a}^{*}$ \\
\hline 1 & -1 & -1 & 67,3 & 13,16 & 13,5 & 2,62 & 2,59 \\
\hline 2 & 1 & -1 & 102,7 & 13,16 & 11,71 & 2,59 & 2,72 \\
\hline 3 & -1 & 1 & 67,3 & 18,84 & 6,97 & 2,33 & 1,96 \\
\hline 4 & 1 & 1 & 102,7 & 18,84 & 13,81 & 2,55 & 2,52 \\
\hline 5 & $-1,41$ & 0 & 60 & 16 & 7,75 & 2,64 & 2,05 \\
\hline 6 & 1,41 & 0 & 110 & 16 & 8,4 & 2,92 & 2,79 \\
\hline 7 & 0 & $-1,41$ & 85 & 12 & 13,5 & 3,39 & 2,52 \\
\hline 8 & 0 & 1,41 & 85 & 20 & 5,92 & 2,28 & 1,79 \\
\hline 9 & 0 & 0 & 85 & 16 & 11,07 & 3,23 & 2,28 \\
\hline 10 & 0 & 0 & 85 & 16 & 11,26 & 3,61 & 2,44 \\
\hline 11 & 0 & 0 & 85 & 16 & 11,87 & 3,42 & 2,38 \\
\hline
\end{tabular}

Table 4. Adjusted models of expansion index (EI), specific volume (SV), and chroma ${ }^{*}$, correlation coefficient $\left(\mathrm{R}^{2}\right)$, and effects of temperature $\left(\mathrm{x}_{1}\right)$ and moisture $\left(\mathrm{x}_{2}\right)$.

\begin{tabular}{|c|c|c|c|c|c|c|c|}
\hline \multirow{2}{*}{ Physical parameter } & \multicolumn{5}{|c|}{ Level of significance (ANOVA) } & \multirow{2}{*}{ Adjusted model } & \multirow{2}{*}{$\mathrm{R}^{2}$} \\
\hline & $\mathrm{T}(\mathrm{L})$ & $\mathrm{T}(\mathrm{Q})$ & $\mathrm{U}(\mathrm{L})$ & $\mathrm{U}(\mathrm{Q})$ & $\mathrm{TxU}$ & & \\
\hline EI & - & 0.01 & 0.04 & 0.01 & & $\mathrm{y}=3.42-0.39 \mathrm{x}_{1}^{2}-0.24 \mathrm{x}_{2}-0.37 \mathrm{x}_{2}^{22}$ & 0.78 \\
\hline SV & - & 0.25 & 0.03 & & 0.06 & $\mathrm{y}=11.22-0,95 x_{1}^{2}-1.90 \mathrm{x}_{2}+2.16 \mathrm{x}_{1} \mathrm{x}_{2}$ & 0.67 \\
\hline$a^{*}$ & 0.005 & - & 0.003 & - & - & $\mathrm{y}=2.37+0.22 \mathrm{x}_{1}-0.24 \mathrm{x}_{2}$ & 0.80 \\
\hline
\end{tabular}

(a)

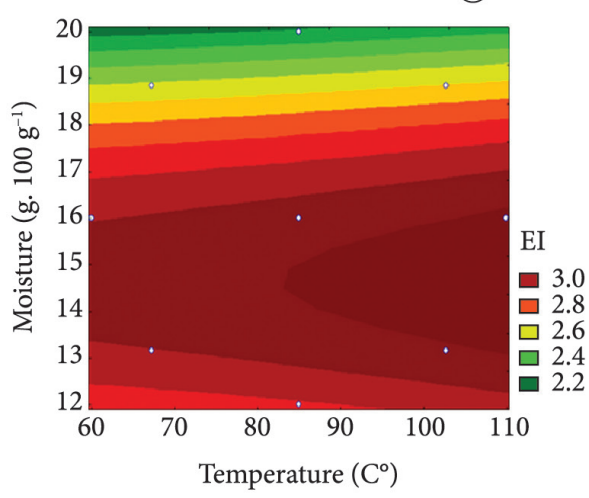

(b)

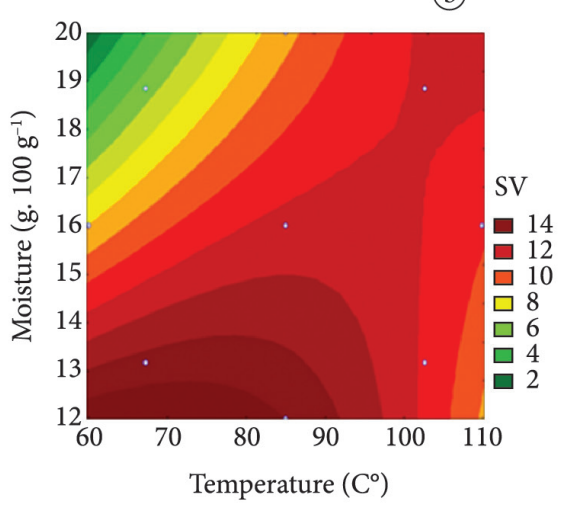

(c)

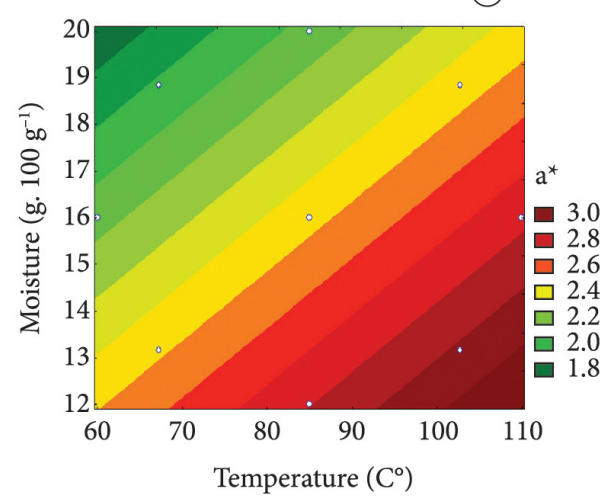

Figure 3. (A) Expansion Index (EI), (B) specific volume (SV) $\left(\mathrm{mL} \mathrm{g}^{-1}\right)$; and (C) chroma $\mathrm{a}^{*}$ of snacks produced from by-products of rice and black soybean according to the mixture's moisture and extrusion temperature in the third zone of the extruder. 
their formulation (CARVALHO et al. (2012). Brightness (L*) of snacks varied between 72.6 and 78 , and chromaticity coordinates $\mathrm{a}^{*}$ and $\mathrm{b}^{\star}$ from 1.79 to 2.79 and from 9.45 to 11.85 , respectively. The effects of moisture and temperature were not significant for $\mathrm{L}^{*}$ and $\mathrm{b}^{*}$; therefore, these parameters were not used in the desirability test because the regressions were not significant $(\mathrm{P}$ $>0.10$ ). Borba, Sarmento and Leonel (2005) reported increased intensity of yellow (increased chrome $b^{*}$ ) when the product was extruded, and they justified this observation as a result of the low moisture content during processing, favoring the occurrence of non-enzymatic browning reactions. In the present study, the intensity of yellow generally increased with lower moisture values (around $12 \mathrm{~g} .100 \mathrm{~g}^{-1}$ ), suggesting an effect of the moisture verified by these authors. The $b^{\star}$ values were also low, differing from those of traditional corn based-snacks, which have high content of carotenoids that provide greater yellowish tint that can be improved with the use of natural dyes such as annatto powder, as reported by Leonel, Souza and Mischan (2010).

With regard to chrome $\mathrm{a}^{*}$, although its variation was small, the positive linear effect of extrusion temperature and the negative effect of the mixture moisture were significant $(\mathrm{P}$ $<0.10$ ). Higher values of chrome $\mathrm{a}^{*}$ (above 2.6) were observed at temperatures above $76.7^{\circ} \mathrm{C}$ and moisture below $16.9 \mathrm{~g} .100 \mathrm{~g}^{-1}$ (Figure 3C). According to Lacerda et al. (2010), the Maillard reactions and caramelization are possible explanations because high temperatures and low humidity in the product processing can make it redder. In accordance with Capriles and Arêas (2012), chrome $\mathrm{a}^{*}$ of snacks of corn and amaranth reached 7.4. On average, the chromaticity $\mathrm{a}^{*}$ of snacks obtained in the present study was three times lower than that of snacks of amaranth and corn. In general, the snacks appeared to be slightly darker (lower $\mathrm{L}^{*}$ values) than the snacks from the rice by-products due to the dark pigmentation of the black soybean okara, despite its lower concentration. The desirable physical properties for the snack were maximum values of EI, SV, and chrome ${ }^{*}$, i.e., as close as possible to those of the snack made from corn grits, the most popular product in the market (Figure 2, experiment 7). The snack from rice and soybean by-products with the highest desirability was obtained with a mixture moisture content of $12 \mathrm{~g} .100 \mathrm{~g}^{-1}$ and extrusion temperature $85^{\circ} \mathrm{C}$ (Figure 4), in which it values of 3.39 were estimated for EI, $13.5 \mathrm{~mL} . \mathrm{g}^{-1}$ for $\mathrm{SV}$, and 2.52 for chromaticity coordinate $\mathrm{a}^{*}$. In the validating the model, the values were very close to these estimated values: SV of $13.25 \pm 0.47 \mathrm{~mL} \cdot \mathrm{g}^{-1}$, EI of $3.36 \pm 0.16$, and chromaticity coordinate $\mathrm{a}^{*}$ of $2.51 \pm 0.03$, confirming the predictive ability of the adjusted models.

The most desirable snack produced from by-products of rice and black soybeans (selected) was analyzed for proximate

Profiles for predicted values and desirability
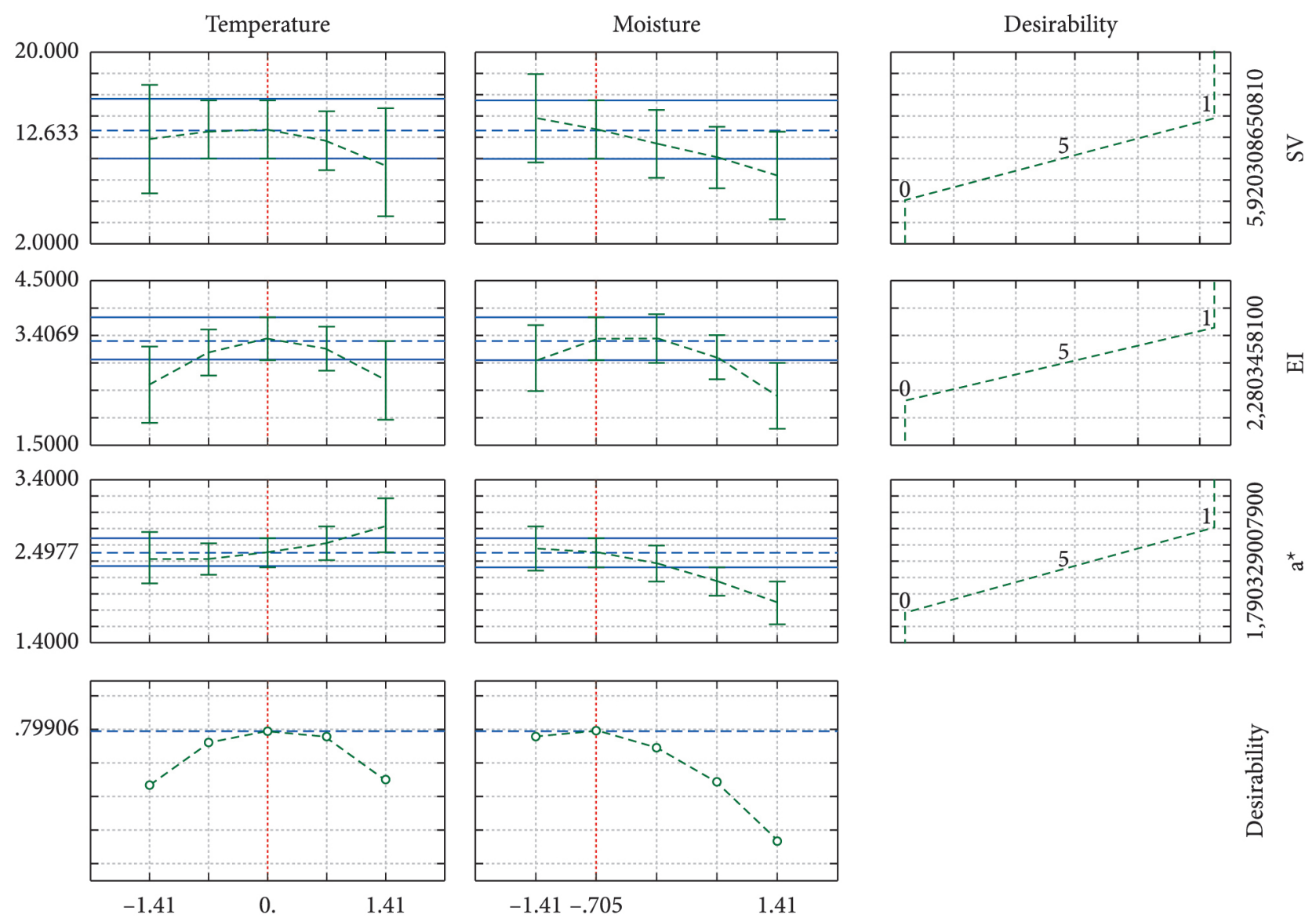

Figure 4. Graphic diagram of desirability aiming to obtain snacks with physical properties required for a product with commercial potential, depending on moisture and extrusion temperature during processing. 
Table 5. Proximate composition and energy value of the optimized snack.

\begin{tabular}{ccc}
\hline Characteristic & $\begin{array}{c}\text { Snack produced from by- } \\
\text { products of rice and soybean }\end{array}$ & Snack of corn ${ }^{2}$ \\
\hline Ashes $^{2}$ & $0.67 \pm 0.01$ & $1.79 \pm 0.06$ \\
Lipids $^{2}$ & $4.08 \pm 0.10$ & $2.49 \pm 0.13$ \\
Protein $^{2}$ & $10.50 \pm 0.12$ & $7.45 \pm 0.80$ \\
Crude fiber $^{2}$ & $1.57 \pm 0.09$ & $2.09 \pm 0,11$ \\
Total carbohydrates $^{2}$ & 79.35 & 62.43 \\
Energy value $^{3}$ & 390.19 & 332.17 \\
\hline${ }^{1}$ Average followed standard deviation; ${ }^{2} \mathrm{~g}$. $100 \mathrm{~g}^{-1}{ }^{3}{ }^{3} \mathrm{kcal}_{(100 \mathrm{~g})^{-1}}{ }^{2}{ }^{2}$ Bombo (2006).
\end{tabular}

composition and energy value, which were compared with those of corn snack obtained by Bombo (2006) (Table 5).

Based on the protein content of the snack produced from rice and soybean by-products, it can be said that it is a source of proteins (Table 5). The experimental snack selected had contents of protein, carbohydrates, and lipids of 41,27 , and $64 \%$, respectively; its ash content was $61 \%$ smaller than that of traditional corn snack (BOMBO, 2006). With regard to the energy value of corn snacks found by Bombo (2006), the value found in the present study was $17.47 \%$ higher due to its lipid content.

\section{Conclusion}

The extrusion conditions that resulted in snacks with the best physical quality (higher expansion and better color) were: moisture of the mixture of rice and soybean by-products of 12 g. $100 \mathrm{~g} \mathrm{~g}^{-1}$ and extrusion temperature of $85^{\circ} \mathrm{C}$. The combination of large amounts of carbohydrates in the broken rice grains with the proteins and lipids of rice bran and black soybean okara resulted in an extruded product of high nutritional value, with $41 \%$ more protein, $64 \%$ more lipids, $27 \%$ more carbohydrate, and energy value $17 \%$ higher than that of the traditional corn snack available in the market. It can be concluded that producing an extruded snack with a mixture of broken grains, rice bran, and soybean okara (81:9:10) is technologically feasible, enabling the development of a new product with good nutritional value that can improve the diet of children, the main consumers of this type of food.

\section{Acknowledgments}

The authors are grateful for the financial support provided by Capes and Fapeg and to Capes for the scholarship granted.

\section{References}

ALVES, R. M. L.; GROSSMANN, M. V. E. Parâmetros de extrusão para produção de "snacks" de farinha de cará. Ciência e Tecnologia de Alimentos, v. 22, n. 1, p. 32-38, 2002. http://dx.doi.org/10.1590/ S0101-20612002000100006

ANGELUCCI, E. et al. Análise química de alimentos. Campinas: Unicamp, 1987. 123 p.
ASCHERI, J. L. R.; CARVALHO, C. W. P. Características Tecnológicas de Expandidos de Arroz e Casca de Soja. Rio de Janeiro: Embrapa, 2006. 2 p. (Comunicado Técnico105)

ASCHERI, J. L. R. et al. Elaboração de "snacks" e farinha instantânea de amaranto / arroz. Rio de Janeiro: Embrapa-CTAA, 2003. 2 p.

ASCHERI, J. L. R. et al. Rendimento e qualidade de grits para extrusão de algumas variedades de milho produzidos pela Embrapa. 2002. Disponível em: $<$ http://www.alice.cnptia.embrapa. br/bitstream/doc/473767/1/Rendimentoqualidade.pdf $>$. Acesso em: 10 maio 2013.

ASSOCIATION OF OFFICIAL ANALYTICAL CHEMISTS - AOAC. Official methods of analysis of AOAC International: Food composition, additives, natural contaminants. 18th ed. Gaithersburg: AOAC International, 2005.

BARBOSA-CÁNOVAS, G. V. et al. Water Activity in Foods: Fundamentals and Applications. Oxford: Blackwell Publishing, 2007. 423 p. http://dx.doi.org/10.1002/9780470376454

BELLAVER, C.; SNIZEK JUNIOR, P. N. Processamento da soja e suas implicações na alimentação de suínos e aves. Concórdia: Embrapa Suínos e Aves, 2009. Disponível em: <http://www.cnpsa.embrapa. $\mathrm{br} / \mathrm{sgc} / \mathrm{sgc} \_$publicacoes/publicacao_x5k97v3r.pdf $>$. Acesso em: 10 jan. 2012.

BOMBO, A. J. Obtenção e caracterização nutricional de snacks de milho (Zeamays L.) e linhaça (Linumusitatissimum L.). São Paulo: Universidade de São Paulo, 2006. Disponível em: <http://bases. bireme.br/cgi-bin/wxislind.exe/iah/online/?IsisScript=iah/iah.xis $\& s r c=$ google $\&$ base $=$ LILACS\&lang $=$ p\&nextAction $=\operatorname{lnk} \&$ exprSear $\mathrm{ch}=444666 \&$ indexSearch=ID $>$. Acesso em: 16 jul. 2013.

BORBA, A. M.; SARMENTO, S. B. S.; LEONEL, M. Efeito dos parâmetros de extrusão sobre as propriedades funcionais de extrusados da farinha de batata-doce. Ciência e Tecnologia de Alimentos, v. 25, n. 4, p. 835-843, 2005. http://dx.doi.org/10.1590/ S0101-20612005000400034

BORGES, J. T. S. et al. Propriedades de cozimento e caracterização físico-química de macarrão pré-cozido à base de farinha integralde quinoa (Chenopodium quinoa, Willd) e de farinha de arroz (Oryza sativa), polido por extrusão termoplástica. Boletim do CEPPA, v. 21, n. 2, p. 303-322, 2003.

BRASIL. Resolução RDC no 360 da Anvisa, de 23 de dezembro de 2003. Regulamento Técnico sobre rotulagem nutricional de alimentos embalados, tornando obrigatória a rotulagem nutricional. Diário Oficial da República Federativa do Brasil, Brasília, DF, 26 dez. 2003.

CAMARGO, K. F.; LEONEL, M.; MISCHAN, M. M. Produção de biscoitos extrusados de polvilho azedo com fibras: efeito de parâmetros operacionais sobre as propriedades físicas. Ciência e Tecnologia de Alimentos, v. 28, n. 3, p. 586-591, 2008. http://dx.doi. org/10.1590/S0101-20612008000300013

CAPRILES, V. D.; AREAS, J. A. G. Avaliação da qualidade tecnológica de snacks obtidos por extrusão de grão integral de amaranto ou de farinha de amaranto desengordurada e suas misturas com fubá de milho. Brazilian Journal of Food Technology, v. 15, n. 1, p. 21-29, 2012. http://dx.doi.org/10.1590/S1981-67232012000100003

CARVALHO, A. V. et al. Processamento e caracterização de snack extrusado a partir de farinhas de quirera de arroz e de bandinha de feijão. Brazilian Journal of Food Technology, v. 15, n. 1, p. 72-83, 2012. http://dx.doi.org/10.1590/S1981-67232012000100008

DIAS, L. T.; LEONEL, M. Caracterização físico-química de farinhas de mandioca de diferentes localidades do Brasil. Ciência e Agrotecnologia, v. 30, n. 4, p. 692-700, 2006. http://dx.doi. org/10.1590/S1413-70542006000400015 
DING, Q. et al. The effect of extrusion conditions on the physicochemical properties and sensory characteristics of rice based expanded snacks. Journal of Food Engineering, v. 66, n. 3, p. 283-289, 2005. http://dx.doi.org/10.1016/j.jfoodeng.2004.03.019

FAUBION, J. M.; HOSENEY, R. C. High temperature and short time. extrusion - cooking of wheat starch and flour. Effect of moisture and flour type on extruded properties. Ceral Chesmistry, v. 59, n. 6, p. 529-533, 1982.

FOOD AND AGRICULTURE ORGANIZATION OF THE UNITED NATIONS - FAO. FAO Rice Market Monitor (RMM). FAO, 2013. v. 16, n. 2, p. 1-2. Disponível em: <http://www.fao.org/economic/ est/publications/rice-publications/rice-market-monitor-rmm/en/>. Acesso em: 20 abr. 2013.

HECK, A. USDA: produção mundial de soja deve atingir 271,03 milhões de toneladas. Campo Grande: Editora Agricultura, 2012. Disponível em: <http://ruralcentro.uol.com.br/noticias/ usda-producao-mundial-de-soja-deve-atingir 27103-milhoes-detoneladas-57599>. Acesso em: 10 maio 2013.

JAEKEL, L. Z.; RODRIGUES, R. S.; SILVA, A. P. Avaliação físicoquímica e sensorial de bebidas com diferentes proporções de extrato de soja e de arroz. Ciência e Tecnologia de Alimentos, v. 30, n. 2, p. 342-348, 2010. http://dx.doi.org/10.1590/S010120612010000200009

KUMAGAI, H.; LEE, B. H.; YANO, T. Flour treatment to improve the quality of extrusion-cooked rice-flour products. Agricultural and Biological Chemistry, v. 51, n. 8, p. 2067-2071, 1987. http://dx.doi. org/10.1271/bbb1961.51.2067

LACERDA, D. B. C. L. et al. Qualidade de farelos de arroz cru, extrusado e parboilizado. Pesquisa Agropecuária Tropical, v. 40, n. 4, p. 521530, 2010. http://dx.doi.org/10.5216/pat.v40i4.7266

LEONEL, M.; SOUZA, L. B.; MISCHAN, M. M. Produção de snacks extrusados à base de polvilho doce e fibra de laranja. Ciência Rural, v. 40, n. 6, p. 1411-1417, 2010. http://dx.doi.org/10.1590/ S0103-84782010000600027

LI, H. et al. The anti-fatigue effect of black soybean peptide in mice. Advances in Material Research, v. 554-556, p. 1475-1482, 2012. http://dx.doi.org/10.4028/www.scientific.net/AMR.554-556.1475
LIMBERGER, V. M. et al. Produção de salgadinho extrusado de quirera de arroz para uso na indústria de alimentos. Ciência Rural, v. 39, n. 9, p. 2590-2594, 2009. http://dx.doi.org/10.1590/S010384782009000900032

LUE, S.; HSIEH, F.; HUFF, H. E. Extrusion cooking of corn meal and sugar beet fiber: effects on expansion properties, starch gelatinization and dietary fiber content. Cereal Chemistry, v. 68, p. 227-234, 1991.

MOLINA, G.; FEIHRMANN, A. C. Bebidas feitas de soja. Higiene Alimentar, v. 23, n. 176-177, p. 29-32, 2009.

PAULCAR-MENACHO, L. M. et al. Desenvolvimento de massa alimentícia fresca funcional com adição de isolado protéico de soja e polidextrose utilizando páprica como corante. Ciência e Tecnologia de Alimentos, v. 28, n. 4, p. 767-778, 2008. http://dx.doi. org/10.1590/S0101-20612008000400002

PESTANA, V. R.; MENDONÇA, C. R. B.; ZAMBIAZI, R. C. Farelo de arroz, características, benefícios a saúde e aplicações. Boletim do CEPPA, v. 26, n. 1, p. 29-40, 2008.

RODRIGUES, M. I.; IEMMA, A. F. Planejamento de experimentos e otimização de processos: uma estratégia sequencial de planejamentos. Campinas: Casa do Pão Editora, 2005. 618 p.

SILVA, J. B.; CARRÃO-PANIZZI, M. C.; PRUDÊNCIO, S. H. Composição química e física de soja tipo grão e tipo alimento para o processamento de alimentos. Pesquisa Agropecuária Brasileira, v. 44 , n. 7 , p. $777-784,2009$. http://dx.doi.org/10.1590/S0100204X2009000700019

SILVA, R. F.; ASCHERI, J. L. R. Etrusão de quirera de arroz para uso como ingrediente alimentar. Brazilian Journal of Food Technology, v. 12, n. 3, p. 190-199, 2009. http://dx.doi.org/10.4260/ bjft2009800900012

SOARES JUNIOR, M. S. et al. Desenvolvimento de salgadinhos extrusados a partir de fragmentos de arroz e de feijão. Semina: Ciências Agrárias, v. 32, n. 1, p. 189-198, 2011.

STASOFT. Statistica 7.0 for Windows - Computar program manual. Tulsa: Statsoft, Inc., 2007. CD-ROOM. 